\title{
Positieve veiligheid en positieve vrijheid
}

\author{
Meningen van wijkbewoners in Rotterdam-Zuid over Buurt \\ Bestuurt
}

Marc Schuilenburg

\section{Inleiding}

Ruim drie jaar geleden, op 17 juni 2013, woon ik voor het eerst een vergadering bij van Buurt Bestuurt in de Rotterdamse wijk Hillesluis. In Buurt Bestuurt bepalen de bewoners, samen met politie en gemeente, welke problemen en uitdagingen in hun wijk als eerste moeten worden aangepakt. Hillesluis ligt in RotterdamZuid en is een van de grootste probleemwijken van Nederland. Het is een achterstandswijk die te maken heeft met een grote werkeloosheid, analfabetisme, criminaliteit en een laag opleidingsniveau. De wijk scoort al jaren slecht op de Rotterdamse Veiligheidsindex, met als laagste score een 4,1 in 2013 (Veiligheidsindex, 2014). Ook op de Sociale Index scoort Hillesluis slecht, een 4,5 in 2012. De buurttevredenheid is met 51 procent in 2010 en 54 procent in 2012 laag (Spierings \& Meeuwise, 2012). Uit een vroeg onderzoek naar Hillesluis blijkt dat vervuiling en gebrekkig onderhoud van de woningen belangrijke problemen zijn. Ook voelen de bewoners zich niet veilig en koesteren ze een breed gevoel van onbehagen (Uit Beijerse et al., 1987, 1990). Meer dan tien jaar later concludeert Blokland (2000, zie ook: 2005, 2009) dat er weinig is verbeterd. Het defaitisme overheerst in Hillesluis en bewoners hebben weinig hoop dat ze de uitkomsten kunnen beïnvloeden van politieke processen over hun wijk.

Ik heb me aangesloten bij Buurt Bestuurt, omdat ik nieuwsgierig ben of de belofte van Buurt Bestuurt in de praktijk wordt waargemaakt. Buurt Bestuurt heeft tot doel de veiligheid en veiligheidsgevoelens onder de bewoners te vergroten. Ook wil het project het onderlinge vertrouwen tussen bewoners en professionals verbeteren door bewoners een actieve stem te geven in de aanpak van problemen in hun wijk. ${ }^{1}$ Dit gebeurt door bewoners te betrekken bij de oplossingen voor de veiligheidsproblemen in hun buurt. Bewoners stellen hun eigen top drie aan problemen in de wijk op en geven die door aan de lokale autoriteiten, waarna de politie en gemeente deze problemen moeten oppakken (Hoekman, 2011; Van der Lindt, 2012; Eysink Smeets, 2013; Van der Land \& Van Stokkom, 2015). Dit maakt het interessant om Buurt Bestuurt als kapstok te gebruiken voor de vraag of met deze nieuwe manier van werken bewoners meer vertrouwen hebben gekregen in de overheid, in het bijzonder in de politie en gemeente.

De bredere relevantie van deze vraag schuilt erin dat Buurt Bestuurt kan worden gepositioneerd tegen de achtergrond van de overgang van de verzorgingsstaat naar een participatiemaatschappij. Ik kom hier nog uitgebreid op terug, maar

1 Zie ook: www.buurtbestuurt.nl. 
voorlopig is het belangrijk te realiseren dat burgers hierin een actievere bijdrage aan publieke taken of voorzieningen van algemeen belang moeten leveren. Zo hebben bewoners in Buurt Bestuurt de mogelijkheid direct invloed uit te oefenen op de beleidskeuze van de overheid om bepaalde veiligheidsproblemen wel of niet aan te pakken. Hiermee onderscheidt Buurt Bestuurt zich van andere veiligheidsprojecten, bijvoorbeeld Burgernet of Amber Alert, waarin burgers slechts worden gebruikt als verlengstuk van de sterke arm - letterlijk miljoenen extra ogen en oren die meedoen in het politiewerk. Tegelijk is Buurt Bestuurt een goed voorbeeld van wat 'positieve veiligheid' (Schuilenburg \& Van Steden, 2014; Schuilenburg, 2016) wordt genoemd, het versterken van positieve connotaties van veiligheid als 'vertrouwen' door bewoners actief te betrekken bij het veiligheidsvraagstuk.

De opzet van dit artikel is als volgt. Allereerst wordt ingegaan op de participatiesamenleving, de culturele en politieke achtergrond waartegen Buurt Bestuurt plaatsvindt. $\mathrm{Na}$ een korte uitleg van de inhoud van het project en de methodiek van onderzoek volgt het verslag van het veldwerk naar de vraag of de bewoners die deelnemen aan Buurt Bestuurt meer vertrouwen hebben gekregen in de politie en gemeente. Op basis van het gepresenteerde interview- en observatiemateriaal ga ik daarbij dieper in op de benoemde problematiek door de bewoners en de mogelijkheid om daarin verandering aan te brengen. Ik besluit met een reflectie of het is gelukt om van Buurt Bestuurt ook echt een ander besluitvormingsinstrument te maken in de veiligheidszorg.

\section{Participatiesamenleving: positieve vrijheid}

Politiek Den Haag wil dat burgers meer maatschappelijke problemen zelf gaan aanpakken. Als spreekbuis van het nieuwe beleid sprak koning Willem-Alexander in zijn troonrede van 2013 van een verandering van de klassieke verzorgingsstaat in een participatiesamenleving. ${ }^{2}$ Deze verandering zou een maatschappij met meer zelfredzaamheid en zeggenschap van de burger moeten betekenen. De troonrede van de koning vormt het sluitstuk van een reeks studies waarin wordt beschreven hoe de eigen verantwoordelijkheid van burgers kan worden versterkt, van huizenbezitters die hun eigen stroom opwekken tot ouders die hun eigen kinderopvang organiseren. Zo publiceerde de Wetenschappelijke Raad voor het Regeringsbeleid (WRR) het rapport Vertrouwen in burgers (2012), het Sociaal en Cultureel Planbureau (SCP) Een beroep op de burger (2012), de Raad voor openbaar bestuur (Rob) Loslaten in Vertrouwen (2012), de Raad voor Maatschappelijke Ontwikkeling (RMO) Terugtreden is vooruitzien (2013) en het kabinet-Rutte Doe-democratie (2013).

2 In de woorden van koning Willem-Alexander: 'Het is onmiskenbaar dat mensen in onze huidige netwerk- en informatiesamenleving mondiger en zelfstandiger zijn dan vroeger. Gecombineerd met de noodzaak om het tekort van de overheid terug te dringen, leidt dit ertoe dat de klassieke verzorgingsstaat langzaam maar zeker verandert in een participatiesamenleving. Van iedereen die dat kan, wordt gevraagd verantwoordelijkheid te nemen voor zijn of haar eigen leven en omgeving.' 
De belofte van de verschuiving van verantwoordelijkheid van Staat naar burgers schuilt voor een belangrijk deel in meer vrijheid voor de burger om een eigen afweging te kunnen maken hoe zijn of haar leven in te vullen. Wie minder staatsbemoeienis wil, moet zorgen dat burgers meer vrijheid hebben om dingen zelf te kunnen doen. Berlin (1969) heeft dit idee onderbouwd aan de hand van het begrippenpaar 'positieve' en 'negatieve vrijheid'. Negatieve vrijheid vormt de kern van het klassieke liberalisme. Deze opvatting van vrijheid beschermt de burger tegen te veel staatsinterventie in het maatschappelijke leven ('vrijheid van'). Positieve vrijheid is een moeilijker te vatten term. Het gaat hierbij om de mogelijkheden van burgers om zich te kunnen ontplooien in de maatschappij ('vrijheid tot'). Deze vorm van vrijheid hangt samen met het vermogen van de burger om zelf zin en vorm te geven aan zijn of haar leven. Taylor heeft erop gewezen dat de term 'vrijheid' onvoldoende wordt geproblematiseerd in het denken van Berlin. Je kunt vrij zijn van externe belemmeringen, maar toch geen greep hebben op je leven door interne obstakels, bijvoorbeeld door angst of onwetendheid. Taylor spreekt daarom van negatieve vrijheid in termen van een opportunity-concept: 'Vrij zijn bestaat uit de mogelijkheden en kansen die je hebt om iets te doen, of we die kansen nu benutten of niet' (1979: 177). Positieve vrijheid daarentegen is een exercise-concept: burgers zijn vrijer naarmate hun vermogen groter is om verantwoorde beslissingen te nemen over hun eigen leven. Dit betekent dat in vrijheid als exercise-concept het probleem centraal staat of iemand zijn plannen ook effectief kan uitvoeren.

Een verdere uitweiding over het begrip 'vrijheid' is hier op haar plaats, omdat het actief en verantwoordelijk maken van burgers voor hun eigen leven niet ongeclausuleerd gebeurt. De participatiesamenleving staat bol van kreten als 'van onderop', 'burgerkracht' en 'de burger aan zet', maar de overheid stelt vaak 'van bovenaf' de spelregels en kaders waarin de burger zijn verantwoordelijkheden geacht wordt te mobiliseren. Peeters en Drosterij (2011) spreken in dit verband van een 'responsabilisering van burgers op voorwaarden van de staat'. Een voorbeeld hiervan zijn buurtbudgetten die bewoners moeten stimuleren om zelfstandig activiteiten te ontwikkelen en uit te voeren om de leefbaarheid in hun wijk te vergroten. Met de hieraan verbonden stringente voorwaarden voor deelname en uitvoering worden er in plaats van kansen vooral obstakels opgeworpen.

Daarnaast hanteert de overheid een dubbele standaard in haar houding ten opzichte van de burger. Aan de ene kant ziet de overheid een belangrijker rol voor de eigen verantwoordelijkheid van de burger voor de aanpak van maatschappelijke problemen, maar aan de andere kant ziet ze diezelfde burger ook als een risicofactor wanneer deze zijn of haar eigen verantwoordelijkheid neemt. Zo wordt de burger in de zorg aangemoedigd om op eigen kracht zorg te regelen via informele netwerken als buurthulp en vrijwilligerswerk, maar tegelijk stuurt de overheid onaangekondigd interventieteams over de vloer bij diezelfde burger om te kijken of er geen sprake is van verwaarlozing of verpaupering (Ombudsman Rotterdam, 2007, 2011; Schuilenburg, 2012). In het geval van de aanpak van criminaliteit en overlast, een ander voorbeeld van de dubbele standaard richting burgers, leunt de politie steeds vaker op de burger om de veiligheid te versterken. Tegelijk wordt de burger zelf steeds scherper geobserveerd door de overheid via 
de opvoering van surveillance en controle. De verschuiving naar een participatiemaatschappij wordt zo dubbel geclausuleerd door de overheid. Niet alleen stelt ze de voorwaarde van een grotere eigen verantwoordelijkheid van de burger, maar behoudt zich daarbij ook nog het recht om voorwaarden te stellen aan die eigen verantwoordelijkheid.

Voor nu is het belangrijk dat over de transitie van een verzorgingsstaat naar een participatiesamenleving een stevig wetenschappelijk debat wordt gevoerd. Er wordt gesteld dat de komst van de participatiesamenleving een beleidsinstrument is voor bezuinigingen, omdat in financieel-economische termen de verzorgingsstaat onhoudbaar is geworden (Rob, 2012; RMO, 2013). Ook wordt er gesproken van kansen om het democratisch tekort tussen verwachtingen ten aanzien van de democratie en de concrete ervaring daarvan te versterken (WRR, 2012) en van een oplossing voor een gebrek aan effectiviteit en een gemis aan legitimiteit van beleid (SCP, 2012). Kortom, de participatiesamenleving kan cynisch worden uitgelegd als een 'ordinaire bezuinigingsoperatie', maar kan ook positief worden opgepakt als een manier om te kijken hoe op lokaal niveau burgers verantwoordelijkheid krijgen voor hun eigen welzijn en leefomgeving.

\section{Vormen van participatie in veiligheid}

Opvallend is dat het debat over de participatiemaatschappij vooral gaat over 'zachte' onderwerpen, zoals leeszalen, tuintjes en zorg voor ouderen, maar dat een 'hard' onderwerp als veiligheid buiten beeld blijft. ${ }^{3}$ Hierdoor ontbreekt een wetenschappelijke discussie over de vraag hoe bewoners zelf waarde kunnen toevoegen aan de veiligheid in hun wijk en aan hun veiligheidsbeleving - de vraag naar 'positieve vrijheid' dus. Dat is des te opvallender, omdat in het huidige hybride veiligheidslandschap de overheid de zorg voor veiligheid uitoefent in samenspraak met tal van andere partijen, van woningbouwbedrijven tot energiebedrijven en van winkeliers tot burgers (Terpstra \& Kouwenhoven, 2004; Terpstra, 2010; Schuilenburg, 2012).

Welbeschouwd hebben burgers altijd al een bijdrage geleverd aan het veiligheidsvraagstuk, van het zelfstandig inbraakvrij maken van hun woning met camera's en dubbele sloten op de deur tot het optreden als getuige op een strafzitting. Desalniettemin zijn in de afgelopen decennia burgers steeds meer betrokken geraakt bij het veiligheidsbeleid. Dit 'publiek maken' van het veiligheidsvraagstuk kent verschillende vormen van participatie - en dus ook van 'publieken' die iedere confictieve identiteit kunnen innemen. Onder 'publieken' versta ik kortstondige of langdurige verzamelingen van burgers met een gemeenschappelijke ervaring of een gemeenschappelijk belang. Ik onderscheid vier vormen van publieke participrojecten. In het rapport Een beroep op de burger van het SCP (2012) is een hoofdstuk gewijd aan 'veiligheid', met als onderwerpen onder meer veiligheidskeurmerken, buurtvaders en Meld Misdaad Anoniem. Opvallend is dat de voorbeelden in beide rapporten beperkt blijven tot vormen van raadplegen en coproduceren. 
paties, die ik hier zo scherp mogelijk verwoord: (1) raadplegen, (2) coproduceren, (3) meebeslissen en (4) zelfbeheer (vgl. Arnstein, 1969). ${ }^{4}$

In Nederland doen burgers voornamelijk mee op de twee lagere niveaus, dat van 'raadplegen' en 'coproduceren'. Ze nemen deel aan slachtofferenquêtes, in het geval van 'raadplegen', of leveren een aandeel aan het opsporingsonderzoek door de politie, bijvoorbeeld via Burgernet ('coproduceren'). In het geval van Burgernet ontvangen de deelnemers een oproep van de politie wanneer er een incident is in hun buurt, bijvoorbeeld een overval, en worden ze opgeroepen uit te kijken naar mogelijke daders. Een ander voorbeeld van 'coproduceren' zijn Marokkaanse buurtvaders (De Jong \& De Haan, 2000; Van Gemert, 2002) die probleemjongeren aanspreken op hun gedrag in een poging ze weer in het gareel te laten lopen. Ook buurtwachten (Van der Land, 2014; Lub, 2016), teams van burgers die patrouilleren door de buurt en daarbij overlastveroorzakers aanspreken (interveniëren) en kijken of er vuil rondslingert of dat verdachte personen zich in de wijk ophouden (signaleren), zijn onder deze trede van burgerparticipatie te scharen. Interessanter zijn de derde en vierde niveaus van participatieprojecten op het gebied van veiligheid. Gaandeweg is er namelijk veel meer ruimte gekomen voor burgers om zelfstandig invulling te geven aan het veiligheidsvraagstuk. Het klassieke geweldsmonopolie van de overheid, zoals dat tot uiting kwam bij denkers als Hobbes ([1651] 1963) en Beccaria ([1764] 1963), komt zo onder druk te staan. Buurt Bestuurt is een voorbeeld van 'meebeslissen', de derde trede van participatie. Burgers hebben hierin inspraak in de vraag waar een deel van de politiecapaciteit aan moet worden besteed door een eigen top drie van problemen op te stellen waar de politie aandacht aan moet besteden. Dit betekent dat het besluit over de aanpak van buurtproblemen verschuift van de overheid naar niet-statelijke partijen. Vergelijkbare initiatieven zijn te vinden in Deventer met het project Buurt Veilig en in Maastricht met Veilige Buurten Teams (Scholte, 2008; Van Stokkom \& Toenders, 2010; Van den Brink \& Bruinsma, 2011; Van der Land \& Van Stokkom, 2015). Relevant hierbij is dat met Buurt Bestuurt op meer dan zestig plekken in Rotterdam de participatiefilosofie verder gaat dan wat de overheid dertig jaar geleden in haar rapport Samenleving en criminaliteit (1985) voor ogen stond. De overheid vond toen dat de deelname van burgers in het veiligheidsbeleid beperkt moest blijven tot raadplegen en coproduceren.

'Zelfbeheer' is de vierde en hoogste trede van participatie. Dit zijn projecten waarin burgers zelfstandig of op eigen kosten voor hun veiligheid zorgen, zonder de inzet van overheidsmiddelen. Het meest bekende voorbeeld hiervan zijn 'gated communities', waarin bewoners hun eigen veiligheid organiseren door commerciele bewakingsdiensten in te huren die hun veiligheidsbeleving moeten vergroten. Deze tendensen naar van de buitenwereld afgescheiden, bewaakte gebieden komen in Nederland nog niet voor. 'Amerikaanse toestanden' zijn hier niet gewoon, de verzorgingsstaat is nog relatief sterk (Schuilenburg \& Van Steden,

4 In de literatuur over veiligheid worden ook andere indelingen gehanteerd. Zo spreken Terpstra en Kouwenhoven (2004) over informatie-uitwisseling, advisering, zelfredzaamheid en zelfbeheer. Scholte (2008) heeft het over toezicht, relationele controle, conflictbemiddeling, beleidsadvisering en -vorming, zelfbeheer en burgerrepressie. 
Marc Schuilenburg

2015). Tot op een bepaalde hoogte geldt dat ook voor eigenrichting, een fenomeen dat ook valt onder 'zelfbeheer'. In Nederland zijn bijna geen voorbeelden bekend waarbij eigenrichting plaatsvond (Van der Land, 2014). Met uitzondering van burgers die aan het begin van de jaren 1990 drugsrunners belaagden in de Rotterdamse wijk Spangen, komen vormen van eigenrichting vooral voor in de Verenigde Staten en Zuid-Afrika ('vigilantes'). Het argument van burgers dat ten grondslag ligt aan initiatieven van zelfbeheer is dat de overheid tekortschiet in haar veiligheidsrol. Zelfbeheer gaat daarom uit van het idee van mensen die samenwerken buiten de Staat en markt om (Uitermark, 2014).

\section{Methode van onderzoek}

Ik heb twee jaar lang deel uitgemaakt van Buurt Bestuurt Rieder-Noord. RiederNoord is een buurt in de wijk Hillesluis. In de regel komt Buurt Bestuurt om de vier weken bijeen. De vergaderingen van Buurt Bestuurt Rieder-Noord vonden in het eerste jaar onregelmatig plaats, soms met tussenpozen van enkele maanden. Met uitzondering van de zomervakantie werd vanaf 2014 iedere maand een vergadering gehouden. In het begin namen ongeveer twaalf bewoners deel aan Buurt Bestuurt, waaronder de directrice van de Basisschool de Piramide. Namens de overheid waren gemeente, politie, stadsbeheer en de organisatie SONOR vertegenwoordigd. ${ }^{5}$ Het aantal bewoners dat deel uitmaakt van Buurt Bestuurt wordt in de loop der tijd steeds minder. Op 11 mei 2015 zaten er nog zeven burgers in Buurt Bestuurt. Naast de vergaderingen van Buurt Bestuurt ben ik ook aanwezig geweest op andere participatiebijeenkomsten in de wijk, onder meer Burgerkracht, Wijktafel Hillesluis en de WIJ-Bijeenkomst Hillesluis.

Naast observaties in de vergaderingen van Buurt Bestuurt zijn de gegevens voor dit onderzoek verkregen via diepte-interviews met de deelnemers van Buurt Bestuurt Rieder-Noord. Er zijn acht semigestructureerde interviews afgenomen met deelnemers in Buurt Bestuurt. Vanaf het begin van het project zijn deze bewoners betrokken geweest bij dit project. Inmiddels heeft een van de geïnterviewde bewoners Buurt Bestuurt verlaten. Ook heb ik gesprekken gevoerd met de vertegenwoordigers van de officiële instanties in Buurt Bestuurt: de participatiemakelaar van stichting DOCK, een organisatie die het zelforganiserend vermogen van mensen en maatschappelijke participatie wil bevorderen, de wijkagent en de gebiedsmedewerker Hillesluis. Daarnaast is de oprichter van Buurt Bestuurt in Rotterdam, Hans Hoekman, geïnterviewd. In deze gesprekken heb ik gevraagd naar hun opvattingen over het functioneren van Buurt Bestuurt Rieder-Noord. Is door Buurt Bestuurt het vertrouwen van de burgers in politie en gemeente toegenomen? Ook heb ik gesproken over de aanpak van de in Buurt Bestuurt benoemde veiligheidsproblemen. Zijn deze problemen wel of niet verbeterd? Daarnaast heb ik gevraagd of de bewoners zich voldoende in staat achten om hun 
keuzevrijheid ook te praktiseren (vrijheid als een exercise-concept, zoals Taylor het verwoordde).

In het tweede deel van het onderzoek is een enquete uitgezet onder de inwoners van Rieder-Noord. ${ }^{6}$ De enquete is ingevuld door 121 burgers. Onder de bereikte steekproef bevonden zich 58 mannen en 63 vrouwen. Nederlandse en Turkse bewoners waren het meest vertegenwoordigd, respectievelijk met 40 en 38 personen. De leeftijden van de geënquêteerden variëren van 14 tot en met 87 jaar. De enquête bestond voor het grootste deel uit waarderingsvragen in de vorm van schaalvragen. Er is onder meer gevraagd naar de veiligheidsproblemen in de wijk, de bekendheid van Buurt Bestuurt in de wijk en of er veranderingen in de wijk zijn gesignaleerd met betrekking tot de aangekaarte veiligheidsproblemen in Buurt Bestuurt. In aanvulling op de enquêtes zijn 61 interviews op straat afgenomen met verschillende bewoners van Rieder-Noord qua leeftijd en geslacht. De interviews zijn gebruikt om meer diepte-informatie te verkrijgen over de bekendheid van Buurt Bestuurt en de problemen in de wijk. Het kortste interview duurde zes minuten, het langste interview 75 minuten. Tot slot zijn tijdens de gehele onderzoeksperiode observaties verricht in Hillesluis om een goed beeld te krijgen van de wijk en de problemen die er spelen.

In de volgende paragrafen ligt de focus vooral op de informatie afkomstig uit het eerste deel van het onderzoek. Op deze manier kan antwoord worden gegeven op de hoofdvraag van dit artikel: 'Leidt de manier van werken in Buurt Bestuurt tot meer vertrouwen van de bewoners in politie en gemeente?' Wanneer dat van toegevoegde waarde is voor een antwoord op de hoofdvraag, betrek ik hierbij ook de uitkomsten van het andere deel van het veldwerk, de enquête, straatinterviews en observaties in de wijk.

\section{Smiley}

Op de eerste vergadering van Buurt Bestuurt Rieder-Noord wordt aan de bewoners gevraagd waar de politie en de gemeente volgens hen extra aandacht aan zouden moeten besteden. ${ }^{7}$ De bewoners komen tot de volgende drie problemen: rondslingerend vuil naast containers, te hard rijden en de parkeerdruk in de wijk. Hoewel het te hard rijden in de wijk op de tweede plaats komt in de top drie aan ergernissen, gaan de meeste discussies in Buurt Bestuurt wel over dit onderwerp. Een hoofdpijndossier, zo zal in het komende jaar blijken. Over hoe de gemiddelde snelheid in de wijk omlaag kan worden gebracht, hebben de bewoners allemaal zo hun ideeën, van het ophogen van de drempels in de straten tot het gebruiken van laserguns door de politie om de snelheid te kunnen controleren. Om het te hard rijden in Rieder-Noord definitief te ontmoedigen, stellen de bewoners uiteindelijk voor een smiley aan te schaffen, een elektronisch verkeersbord dat bestaat uit een gele cirkel - een gezicht - met twee stippen daarin - ogen en mond. Afhankelijk

6 Graag bedank ik de studenten die aan het tweede deel van het empirische onderzoek hebben meegedaan: Danielle Brouwer, Jolien de Bruijn, Muriëlle Duineveld, Martijn Voogd en Vasilis Zachos.

7 Delen van deze paragrafen zijn gebaseerd op Schuilenburg (2015). 
van de snelheid waarmee een auto het bord passeert, lacht het gezicht (als de automobilist goed rijdt) of kijkt het bedroefd (als de automobilist te hard rijdt). Het idee is dat de gelaatsuitdrukking van het waarschuwingsbord chauffeurs motiveert om zich aan de geldende snelheidsregels te houden, ook wel 'nudging' genoemd (Schuilenburg \& Peeters, 2015).

In de vergadering van 17 juni 2013 zijn alle bewoners het erover eens dat de smiley een einde kan maken aan het snelheidsprobleem in de wijk. Om de effectiviteit van het middel zo groot mogelijk te maken, stellen de bewoners voor de smiley steeds in die straten te zetten waar te hard werd gereden - eerst aan de ene kant van de straat en dan aan de andere kant. Goed idee zou je zeggen, maar zo niet de gemeente. De lijst van redenen om het verzoek van de bewoners af te wijzen, is eindeloos. Eerst wordt gesteld dat burgers niet zelf een smiley mogen plaatsen, zelfs niet in hun voortuin of aan de gevel. Ook vindt de gemeente dat de kosten van een smiley te hoog zijn (ongeveer $€ 1000$ per maand). Bovendien zouden de twee smiley's van Stadsbeheer al in gebruik zijn om weggebruikers in de wijk op een vriendelijke en directe manier te wijzen op zijn of haar snelheid. En ten slotte, zo wordt gesteld, zijn de verzoeken om plaatsing van een smiley niet aan de juiste instantie gericht. Het blijken later vooral gelegenheidsargumenten te zijn.

De patstelling tussen gemeente en bewoners duurt ruim een jaar. Uit woede en frustratie besluiten de bewoners in de vergadering van 10 april 2014 om een brief over de kwestie aan burgemeester Aboutaleb te schrijven. Een maand later komt de smiley opnieuw ter sprake in Buurt Bestuurt, nu in het bijzijn van de voorzitter van de gebiedscommissie Feijenoord en de directeur gebied Feijenoord. De bewoners geven aan dat ze de hele situatie onbegrijpelijk vinden. Net als iedere andere Buurt Bestuurt in Rotterdam hebben ze een budget om zelfstandig aankopen te doen of initiatieven te ontplooien. Maar dit budget kan niet worden aangewend voor de aankoop van een smiley, omdat de gemeente hiervoor geen toestemming geeft. De directeur gebied Feijenoord geeft aan 'niet langer in een cirkel te willen redeneren'. En stelt: 'Ik kom hierop terug.' Op de vergadering van 16 juni 2014 gaat het ongeorganiseerde bureaucratische proces verder. Inmiddels heeft Stadsbeheer een e-mail aan een bewoner van Buurt Bestuurt gestuurd met uitleg over de smiley. De e-mail leidt vooral tot verwarring bij de bewoners. Zo schrijft Stadsbeheer: 'Allereerst vinden wij het niet nodig dat jullie als Buurt Bestuurt zelf een SID (smiley) gaan aanschaffen terwijl het gebied er over 2 kan beschikken.' Verschillende bewoners merken op dat de insteek van de mail van Stadsbeheer erg negatief is. 'Ze vinden dus dat we geen smiley hoeven te hebben', zegt een bewoonster. Maar verder in de mail vraagt Stadsbeheer aan de bewoners om 'een lijstje op te stellen met de straten waar jullie de SID willen ophangen'. Vanwege de onduidelijkheid van de inhoud van de e-mail, 'wel of geen smiley?', stelt de vertegenwoordiger van de gemeente voor de dienst Stadsbeheer uit te nodigen voor de volgende bijeenkomst van Buurt Bestuurt.

Op 14 juli 2014 is de vertegenwoordigster van Stadsbeheer in Buurt Bestuurt aanwezig en kan niet anders dan toegeven dat de bewoners vanaf 1 september een smiley in bruikleen kunnen krijgen. Misschien versprak zij zich, toen zij daarop liet volgen dat er nog een ongebruikte smiley in een opslag lag. Hoe het ook zij, 
het verhaal over de kosten van de smiley werd daarmee meteen ongeloofwaardig en de gemeente moest ten langen leste een smiley in Rieder-Noord plaatsen. Had dezelfde smiley de gemoedstoestand van de bewoners in Rieder-Noord gedurende de bijeenkomsten van Buurt Bestuurt weergegeven, dan zou het waarschijnlijk voortdurend boos hebben gekeken. Boos vanwege de bestuurlijke onwil en de talloze bureaucratische blokkades waarmee zij voortdurend werden geconfronteerd. 'Als buurt mag je blijkbaar geen smiley hebben, ik kan het niet anders verklaren', zegt een bewoner.

De hele gang van zaken laat diepe sporen achter bij de bewoners. De slechte ervaringen met de komst van de smiley voeden het idee onder bewoners dat ze in Buurt Bestuurt geen macht hebben om de wijk te besturen. Het volgende citaat van een bewoonster is hiervoor illustratief: 'Volgens mij wordt er niet bestuurd in Buurt Bestuurt. Is het woord "besturen" wel goed? Of de "Buurt Praat Mee"? Als het Buurt Bestuurt is, dan zie ik dat niet zo gebeuren. Hier is het "Buurt Bestuurt Niet".' Andere deelnemers spreken van een vertrouwenskwestie tussen de bewoners en de overheid en vertellen in de interviews dat ze weinig tot geen vertrouwen meer hebben in de politie en gemeente.

'Het is vechten tegen de bierkaai. Echt waar. Daarom geven ook veel mensen op. We komen met het idee om zelf een smiley te kopen. We wisten namelijk dat het een jaar of anderhalf jaar zou duren voordat we er een zouden kunnen krijgen. En dan zou dat ook maar voor drie maanden zijn. En dan komt Stadsbeheer een keer bij Buurt Bestuurt zitten en dan hangt dat ding er opeens binnen een maand. Het is zo belachelijk dat dit zo werkt. Die instanties laten het zo afweten.'

Voor één bewoner is de smiley zelfs reden om uit Buurt Bestuurt te stappen: 'Sturen we een brief naar het stadshuis, dan blijkt opeens dat Stadsbeheer al een paar jaar er één heeft liggen. Dat was voor mij een hele grote druppel om ermee te stoppen. Waarom zegt Stadsbeheer niet meteen dat ze een reserve smiley hebben liggen?'

\section{Doorzettingsmacht}

Op een dieper niveau is de onmacht en frustratie van de wijkbewoners een gevolg van een al te blijmoedige opvatting over het zelforganiserend vermogen van de burger. In talloze studies naar actief burgerschap wordt gesteld dat alle burgers als competente vertegenwoordigers van de publieke zaak kunnen optreden. Voorstanders van de participatiesamenleving gaan daarmee uit van goed opgeleide burgers die in staat zijn problemen te analyseren en op te lossen. Oplossingen die ze op rationele wijze weten over te brengen aan de overheid. Opvallend is dat 'de burger' hierbij nooit wordt geproblematiseerd. De term 'burger' wordt vooral positief gehanteerd, in de betekenis van een weldenkend persoon die tijd en zin heeft om te participeren in het veiligheidsvraagstuk. Er zijn echter serieuze vraagtekens te plaatsen bij de veronderstelde burgerkracht in de participatiesamenle- 
Marc Schuilenburg

ving (vgl. Van Stokkom, 2008). Illustratief hiervoor is de volgende opmerking van een medewerker van de gemeente over de participatiegraad van de bewoners: 'Er zijn in Buurt Bestuurt maar twee mensen die echt over de problemen mee kunnen praten. De rest zit er gewoon bij en wil het niet al te ingewikkeld hebben.' Ook de bewoners geven aan dat ze het lastig vinden om veiligheidsproblemen zelf aan te pakken of dit te doen in overleg met de gemeente en politie:

'Ik denk dat Buurt Bestuurt er vooral is om sociale initiatieven te organiseren, bijvoorbeeld een speurtocht in de wijk of een kennistour over de geschiedenis van de buurt. Dit kunnen we zelf doen. Andere zaken niet. Neem bijvoorbeeld de drugsproblematiek. Wat kunnen wij hieraan doen? We kunnen dit aankaarten, maar meer dan dat kunnen we niet doen. Hetzelfde is met hardrijden. Het is toch aan de politie om hier wat aan te doen.'

Wanneer bewoners een jaar lang bezig zijn om een smiley te krijgen, die bovendien alleen gebruikt mag worden op de door de gemeente gestelde voorwaarden, dan kun je vragen stellen over de bureaucratische molens waarin de veiligheidsbehoefte die bestaat onder de mensen, is beland. Ook kun je twijfels hebben of in een kort tijdsbestek van hooguit enkele maanden resultaten kunnen worden geboekt. Maar je kunt ook vragen stellen bij de bestuurlijke en operationele doorzettingsmacht van de burger. Is die altijd voldoende om door de bureaucratische bastions heen te breken? De wijkbewoners die deel uitmaken van Buurt Bestuurt Rieder-Noord geven in de gesprekken aan dat ze het gevoel hebben niet bij machte te zijn om de door hen gewenste besluiten door te drukken. Dat komt doordat ze eigenlijk niet weten hoe, want 'de gemeente zit op de Coolsingel en niet hier', en omdat 'er een stukje kennis en ervaring ontbreekt om zelf iets te kunnen regelen'. Zoals Tonkens (2009) heeft opgemerkt, brengen de bewoners vooral hun 'ervaringsdeskundigheid' in over de wijk en de problemen, niet 'beleidsdeskundigheid' om problemen daadwerkelijk aan te kunnen pakken. Dit maak ik ook mee tijdens de vergadering van Buurt Bestuurt van 14 juli 2014. Op de vraag van de wijkregisseur wie van de bewoners het voortouw wil nemen om Buurt Bestuurt breder bekend te maken in de wijk, is het antwoord: 'Dit is een anarchistisch zooitje. Je kan niet teveel van ons verwachten.'

Uit een studie van Engbersen et al. (2015) blijkt dat laag opgeleide bewoners niet goed in staat zijn verantwoordelijkheid te nemen voor bepaalde maatschappelijke problemen volgens de principes van de participatiesamenleving. In dezelfde studie komt naar voren dat allochtone bewoners minder participeren in de samenleving dan autochtone bewoners. Daarentegen is die burgerkracht wel in voldoende mate aanwezig in de beter gesitueerde wijken van steden - bijvoorbeeld Hillegersberg of Kralingen-Oost in Rotterdam - waar het hogere segment van de bevolking woont. De bemiddelde en hoogopgeleide Rotterdammers hebben wel de juiste contacten en weten zich, door opleiding en ervaring, in de regel prima te verweren tegen ambtenaren en autoriteiten. Dit wordt ook bevestigd in de interviews met de burgers van Rieder-Noord. Zo vertelt een deelnemer van Buurt Bestuurt: 'Rotterdam-Zuid is de boerenafdeling van Rotterdam. In Hillegersberg zullen mensen sneller en makkelijker een brief schrijven, bellen met de politie, of 
iemand aanspreken. Dat lukt hier zelden of nooit.' Een andere bewoner vertelt: 'Het hangt sterk af in welke wijk je woont of er naar je wordt geluisterd. Dat zie je bijvoorbeeld met het plaatsen van de vuilcontainers onder de grond. Dat heeft bijna drie jaar geduurd omdat de ontwerpers niet wilden dat hun groenontwerp werd verstoord.' Over de oorzaken waarom bewoners zich zo passief opstellen hebben de bewoners verschillende verklaringen. Opleiding en onvoldoende tijd, worden vaak geopperd. Maar ook het ontbreken van, wat in de literatuur wordt genoemd, 'overbruggend sociaal kapitaal' (bridging), waarin relaties worden aangegaan met mensen die over andere kennisbronnen beschikken (Putnam, 2000), speelt een rol. Een bewoner vertelt mij: 'Veel bewoners werken 's nachts in de haven of in de bouw en kennen niet iemand die bij een accountantskantoor werkt en die voor hen een brief kan schrijven.' Hiermee wordt gewezen op het feit dat de respondenten niet beschikken over 'makelaars' of 'bruggenbouwers' (Van Eijk, 2010: 68), mensen die individuen en netwerken met elkaar verbinden die anders niet met elkaar verbonden zouden zijn.

Dat in het beleid om de burger meer te laten participeren in het veiligheidsvraagstuk niet wordt gedifferentieerd tussen burgers en buurten is opvallend. Niet alleen omdat er tussen, maar ook in de wijken zelf grote verschillen tussen burgers zijn. Zo hebben de meeste wijkbewoners in Hillesluis vaak andere, grotere zorgen - werkloosheid, schulden, huiselijk geweld - aan hun hoofd. Voor bewoners van deze achterstandswijk is het vrij lastig om volwaardig mee te kunnen doen, want zoals een gebiedsmedewerker van de gemeente tegen mij vertelt: 'In deze buurt zijn mensen de godganse dag bezig te overleven. Als je mensen vraagt om iets te betekenen voor hun omgeving, dan doen ze het niet zo snel. Mensen hebben zat problemen en kunnen er lastig dingen bij doen. Dat lukt ze niet, dat is veel te ingewikkeld.' Ook de participatiemakelaar van stichting DOCK deelt deze mening:

'Ik denk dat een instrument als Buurt Bestuurt alleen werkt in gemeenten waar bewoners al veel kunnen. Waarin ze veel tools hebben en niet bang zijn om hun verantwoordelijkheid te nemen. Zij staan sterker, weten hun weg te vinden. In dit soort wijken hebben de mensen de vaardigheden niet. Ze hebben een gering netwerk om dingen voor elkaar te krijgen. Ze missen basale vaardigheden, bijvoorbeeld een mailtje kunnen sturen of een afspraak nakomen.'

Deze waarschuwingen zijn niet nieuw. Het zijn terugkerende lessen. Concreet betekenen ze dat het serieus nemen van burgers ook inhoudt dat moet worden ingezien dat de vaardigheden om te participeren niet gelijk zijn verdeeld. Tegelijk roept dit alles de vraag op hoe Buurt Bestuurt dan kan bijdragen aan de versterking van een positieve connotatie van het begrip 'veiligheid', in dit geval 'vertrouwen' in publieke professionals. Immers, een van de doelstellingen van Buurt Bestuurt is het vergroten van het vertrouwen van burgers in de politie en gemeente. Volgens de WRR (2012) vormt vertrouwen zelfs de sleutel voor een participatiemaatschappij die bouwt op burgerbetrokkenheid. 


\section{Een kwestie van vertrouwen}

In deze casus blijkt 'vertrouwen' buitengewoon lastig te omschrijven. Gaat het bijvoorbeeld om het vertrouwen van de bewoners in zichzelf, de wijkagent of in de gemeente? Zo merkt een bewoner tegen mij op: 'Door Buurt Bestuurt heb ik niet meer vertrouwen in de gemeente gekregen. Ik zie politici meer als praters. Niet als doeners.' Volgens Luhmann (2000) is vertrouwen een mechanisme om de sociale complexiteit te reduceren, een manier om het leven zowel eenvoudiger te maken als om te gaan met risico's en onzekerheid. Hij spreekt over vertrouwen in termen van een 'riskante Vorleistung', een soort beloning vooraf voor wat nog geleverd moet worden.

Een onderscheid kan hierbij worden gemaakt tussen de betekenissen van de Engelse woorden 'trust' en 'confidence'. 'Trust' is een relationeel begrip, iets wat zich afspeelt tussen personen, bijvoorbeeld het vertrouwen dat iemand heeft in een ander. Deze vorm van vertrouwen is actief van aard. Je kiest ervoor, met alle risico's die daarbij horen, iemand te vertrouwen. Naast 'vertrouwen in' is er ook 'vertrouwen op', een passievere vorm die terugkeert in het woord 'confidence'. Hierbij gaat het om institutioneel vertrouwen (Lipset \& Schneider, 1983; Schuyt \& Verhoeven, 2003). Zo vertrouwen burgers erop dat de overheid niet discrimineert. Ook kan het hierbij gaan om vertrouwen op bepaalde sociaal-culturele normen die burgers in de loop der tijd zich eigen hebben gemaakt en aan elkaar overdragen. Sociaal vertrouwen is dan de combinatie van 'institutioneel vertrouwen' ('vertrouwen op') en vertrouwen tussen individuen ('vertrouwen in'). ${ }^{8}$ Beide noties van vertrouwen hoeven niet altijd samen te gaan (Goldsmith, 2005; Jackson et al., 2013). Sommige personen, zo blijkt uit interviews met de deelnemers en de andere bewoners in de wijk, hebben wel 'vertrouwen in' de gebiedsmedewerker en de wijkagent, maar 'vertrouwen op' de gemeente en de politie, dat doen ze veel minder. Andere bewoners wantrouwen de politie zelfs.

Om meer grip te krijgen op de paradox dat de deelnemers aan Buurt Bestuurt overwegend positief zijn over de wijkagent en gebiedsmedewerker, maar weinig of niet vertrouwen op de overheid, bespreek ik hier drie dimensies van vertrouwen die uit de interviews en observaties naar voren zijn gekomen: (1) prestaties, (2) intenties en (3) competenties. Vertrouwen, of een gebrek daaraan, doet zich allereerst voor in ruilsituaties tussen burgers en professionals, bijvoorbeeld in het geval van het leveren van een concrete prestatie door de ene partij aan een andere partij. Dit is 'de instrumentele kant' van vertrouwen (Goldsmith, 2005; Meurs,

8 In aanvulling hierop kan een derde vorm van vertrouwen worden onderscheiden die meer naar binnen is gericht. Er is namelijk ook sprake van zelfvertrouwen of van het zelfbeeld van de bewoners in de wijk. Het negatieve imago van wonen in een achterstandswijk als Hillesluis bijvoorbeeld zou dan kunnen leiden tot gevoelens van vernedering en minachting (vgl. Wacquant, 2008). Zo maakte ik op 2 juni 2014 een Wijktafeldiscussie mee waarvoor alle bewoners van Hillesluis waren uitgenodigd. De idee hierachter is dat burgers met elkaar kunnen discussiëren over de wijk en hun grieven en wensen ter plekke kenbaar kunnen maken aan de aanwezige ambtenaren. Het valt me op dat meerdere bewoners spreken over een stigma om te wonen in Hillesluis. Illustratief hiervoor is de uitspraak: 'We hebben een bepaalde stempel, zo voelen kinderen het ook hier.' 
2008, 2014). Vertrouwen is dan het ruilen van prestaties - binnen onderlinge relaties. Het ontstaat wanneer een prestatie beantwoordt aan de verwachtingen van de andere partij. Het wekt in dit verband geen verbazing dat de kwestie rondom de smiley voor een groot deel van de deelnemers een grote bron van frustratie en irritatie is. Het uitblijven van de smiley leidt ertoe dat de deelnemers ook bij de twee andere benoemde problemen uit hun top drie weinig tot geen vertrouwen meer hebben in de aanpak van de gemeente en politie. Om tot een structurele oplossing voor het vuilprobleem te komen bijvoorbeeld, stellen de bewoners voor om de containers op de middenberm van de Slaghekstraat onder de grond te plaatsen. Uit de gesprekken met de gemeente in Buurt Bestuurt blijkt dat dit lastig is te realiseren. Zo is de gemeente van mening dat de middenberm is gelabeld als 'groenstrook', waardoor de containers niet ondergronds mogen worden geplaatst. Dit roept weer vraagtekens op bij de bewoners, omdat de middenberm in werkelijkheid helemaal niet zo groen is: 'Zelfs je hond zou er nog omheen lopen.'

Vertrouwen speelt ook bij de tweede dimensie van intenties. Hierbij gaat het niet om een prestatie of om competenties, maar om 'de mate waarin partijen in elkaars goede bedoelingen geloven: Ben je te vertrouwen? Ben je mijn vertrouwen waard?' (Meurs, 2014: 9). Wanneer dit niet het geval is, kan dit leiden tot het wantrouwen van de ander. Meerdere keren geven de geïnterviewde Hillesluisers uitdrukking aan hun gevoel van wantrouwen over de goede bedoelingen van de gemeente. Zo zegt een deelneemster aan Buurt Bestuurt: 'Ik weet niet of ik in complotten moet denken, maar ik heb het idee dat het niet de bedoeling was dat de bewoners een Smiley zouden krijgen - of er nu een in de kast lag of niet.' Een andere bewoonster koppelt haar wantrouwen in de intenties van de gemeente aan het missen van macht om te kunnen besturen: 'Ik voel geen macht in Buurt Bestuurt om dingen voor elkaar te krijgen. Als ik zou zeggen: Ik vind het een saaie bedoening hier in de buurt, ik wil overal bloembakken, dan zal dat niet gebeuren. Die macht heb je niet. Er wordt heel gauw gezegd dat mag niet en dat kan niet.' In het geval van vertrouwen in de competenties - de kwalificaties en expertise van de officiële instanties in Buurt Bestuurt ligt de situatie genuanceerder. Wie geen vertrouwen in iets of iemand heeft, zegt ook dat de andere partij te weinig blijk geeft van kwaliteiten of competenties die in het gegeven geval verwacht mogen worden (Schnabel, 2010). In het geval van een negatieve beoordeling van de competenties van een partij kan dit leiden tot de situatie dat er 'geen vertrouwen' is in die ander. Zo spreken veel burgers het gevoel uit dat ze geen vertrouwen hebben in de politie en overheid, iets wat in het citaat van een bewoner aan het begin van deze paragraaf al naar voren kwam. Maar in de gesprekken wordt ook meerdere keren aangegeven dat bewoners wel te spreken zijn over zowel de wijkagent als de gebiedsmedewerker van de gemeente. Zo zegt een bewoner over 
de laatste persoon: 'Ik vind dat hij het goed doet. Hij is direct en gaat er gelijk achter aan. Wanneer ik hem mail, krijg ik altijd binnen een uur antwoord.'

\section{Conclusie en reflectie}

Uit de Rotterdamse Veiligheidsindex en eerdere onderzoeken naar Hillesluis doemt een beeld op van een wijk die gebukt gaat onder de onveiligheid en die veel te lijden heeft van overlast. Met de komst van de participatiesamenleving lijkt nadrukkelijk weer aandacht te komen voor het uitgangspunt dat oplossingen voor dergelijke problemen moeten worden gevonden in de wijk zelf - en niet bij de overheid. Buurt Bestuurt is hierbij een proeftuin bij uitstek, want ze biedt inzicht in de vragen hoe burgers participeren in de veiligheidszorg en of de introductie van dit instrument leidt tot meer vertrouwen van burgers in politie en gemeente. Maar lukt het in de praktijk om van Buurt Bestuurt ook echt een ander besluitvormingsinstrument te maken?

Voordat ik hierop een antwoord geef, is het belangrijk om te realiseren dat de omslag naar een participatiemaatschappij tot verschillende paradoxen leidt. De belangrijkste participatieparadox is dat de overheid in het veiligheidsbeleid een dubbele boodschap uitzendt - en dat is lastig voor burgers om te begrijpen. Zo mogen burgers in participatie-instrumenten als Buurt Bestuurt meebeslissen welke problemen door politie en gemeente worden opgepakt, een versterking van de positie van de burger in het veiligheidsvraagstuk. Maar burgers worden ook gezien als een risico voor de veiligheid en zijn in het dagelijks leven object geworden van meer voorzorg, zero tolerance, surveillance, controle en bewaking (Simon, 2007; Schuilenburg, 2012). De gedachte die naar voren komt in het raamwerk van 'positieve veiligheid', dat zaken zoals vertrouwen, geborgenheid en zorg positief moeten worden gestimuleerd door bewoners nauwer te betrekken bij het veiligheidsvraagstuk, wordt zo gebracht met meer 'negatieve veiligheid', het bestrijden van onveiligheid met een sterke nadruk op verbieden, afschrikken en beboeten. Scherp gesteld komt de gespletenheid van de veiligheidsboodschap dan op het volgende neer: de overheid belooft positieve veiligheid, maar geeft vooral negatieve veiligheid.

Daarnaast heb ik laten zien dat om veiligheid een afspiegeling te laten zijn van de behoeften van bewoners, er goed moeten worden gekeken naar de competenties van de deelnemende partijen aan Buurt Bestuurt. Anders wordt Buurt Bestuurt de panacee voor elk veiligheidsprobleem zonder dat wordt gelet op de voorwaarden om van Buurt Bestuurt een succes te maken. Dat zou teleurstellend zijn, omdat

9 De kwestie van vertrouwen speelt niet alleen tussen burgers en overheid. Ook de politie en gemeente verwoorden in de interviews gevoelens van frustratie over het feit dat de dienst Stadsbeheer bijvoorbeeld zelden aanwezig is in de vergaderingen van Buurt Bestuurt. Zo zegt de wijkagent: 'Ongeïnteresseerd, denk ik, laksheid. Ik kan niets anders verzinnen.' De vertegenwoordiger van de gemeente stelt: 'Ik stoor me mateloos aan het feit dat Stadsbeheer er bijna nooit bij zit. Ze zijn namelijk ontzettend belangrijk in Buurt Bestuurt. Het is een onafhankelijk orgaan, dus als zij vinden dat ze niet aanwezig hoeven te zijn, doen ze het ook niet zo snel. Ze willen natuurlijk ook niet teveel klachten horen van de bewoners.' 
uit internationale studies blijkt dat vergelijkbare projecten een beproefd middel zijn om onveiligheid in achterstandswijken te bestrijden en het vertrouwen tussen bewoners en professionals te vergroten (Fung, 2004; Carr, 2005; Skogan, 2006). In deze casus blijkt onder meer dat burgers concrete vermogens en vaardigheden missen om de kans (opportunity) die ze wordt geboden om mee te beslissen in het veiligheidsbeleid ook te benutten (exercise). Dit roept een belangrijke vraag op, die onlosmakelijk samenhangt met een positive turn in het veiligheidsvraagstuk: 'Hoe kan positieve vrijheid, in de betekenis van een exercise-concept, in samenhang met positieve veiligheid worden versterkt?' Want zoals hier blijkt: keuzevrijheid is nog geen keuzevermogen.

Om juiste keuzes te kunnen maken, is er in ieder geval vertrouwen nodig tussen burgers en publieke professionals. De ruimte is hier te beperkt om nu tot in detail alle bevindingen hierover samen te vatten. Maar als er een conclusie in de casus van Buurt Bestuurt Rieder-Noord uitspringt, is het wel dat vertrouwen uitspreken niet hetzelfde is als vertrouwen voelen of vertrouwen krijgen. Vertrouwen is een zachte positieve waarde van veiligheid, ongetwijfeld (vgl. Van Marle, 2015; Bakker, 2015). Toch blijkt vertrouwen op tal van expliciete en minder expliciete manieren een belangrijke rol te spelen in de relatie tussen burger en overheid, met name met betrekking tot de prestaties van diezelfde overheid. De komst van de smiley in Rieder-Noord staat hiervoor symbool. Hiermee bedoel ik dat overheidsbeleid ongeloofwaardig wordt wanneer enerzijds tegen bewoners wordt gezegd: meer zelf doen, en anderzijds het in de praktijk onmogelijk wordt gemaakt om in gang gezette initiatieven van diezelfde burgers door te laten gaan. Het is dan lastig om als burger vertrouwen terug te geven aan de overheid. En de overheid wil dat vertrouwen graag, maar dan moet er wel sprake zijn van hulp en steun naar de burger toe.

Kortom, wanneer beleidsmakers en politici willen dat bewoners participeren in het veiligheidsvraagstuk, dan dienen ze ook na te denken in welke verschillende vormen vertrouwen komt. Heeft vertrouwen te maken met het sociaal kapitaal in de wijk (Putnam, 2000), met de prestaties van de overheid (Lipset \& Schneider, 1987), of met het optreden tegen en de bejegening van de burger door de overheid (Tyler, 2001)? Wie denkt het vertrouwen tussen burgers en de overheid met simpel het introduceren van nieuwe veiligheidsinstrumenten als Buurt Bestuurt te kunnen versterken, komt van een koude kermis thuis. Daarvoor is meer nodig.

\section{Literatuur}

Arnstein, S.R. (1969), A ladder of citizen participation. Journal of the American Institute of Planners, (35)4, 216-224.

Bakker, G. (2015), Positieve veiligheid. Een theoretische analyse van een omstreden begrip. Tijdschrift voor Veiligheid, (14)2, 36-52.

Beccaria, C. ([1764] 1963), On Crimes and Punishments. New York: Prentice-Hall.

Beijerse, J. uit, H. Moerland \& C. Fijnaut (1987), Boulevard Zuid. Een winkelstraat met problemen?. Rotterdam: Centrum voor Geïntegreerde Strafrechtswetenschap. 
Beijerse, J. uit, H. Moerland \& C. Fijnaut (1990), Problemen in en stadsvernieuwingswijk in Rotterdam-Zuid. Meningen van mensen die er werken en/of wonen. Rotterdam: Centrum voor Geïntegreerde Strafrechtswetenschap.

Berlin, I. (1969), Four Essays on Liberty. Oxford: Oxford University Press.

Blokland, T.V. (2000), Politiek als curiositeit: Over milieu, dominantie en politieke participatie. In: F. Hendriks \& P. Tops (red.), Stad in spagaat. Institutionele innovatie in het stadsbestuur. Assen: Van Gorcum, 81-95.

Blokland, T.V. (2005), Goeie buren houden zich op d'r eigen: Sociale relaties in de grote stad. Den Haag: dr. Gradus Hendriks Stichting.

Blokland, T. (2009), Oog voor elkaar. Veiligheidsbeleving en sociale controle in de grote stad. Amsterdam: Amsterdam University Press.

Boutellier, J.C.J., I. Groot, S. Nieborg, S. Tan \& R. van Wonderen (2007), Sociaal vertrouwen in Oud-Zuid: Literatuurverkenning en ontwikkeling van een meetinstrument, Utrecht: Verwey-Jonker Instituut.

Brink, G. van den \& M. Bruinsma (red.) (2011), De aanhouder wint. Samenwerken aan veilige krachtwijken. Den Haag: Ministerie van Buitenlandse Zaken en Koninkrijksrelaties.

Carr, P.J. (2005), Clean Streets: Crime, Disorder and Social Control in a Chicago Neighborhood. New York: New York University Press.

Eijk, G. van (2010), Unequal Networks. Spatial Segregation, Relationships and Inequality in the City. Amsterdam: Delft University Press.

Engbersen, E., E. Snel \& M. 't Hart (2015), Mattheüs in de buurt: over burgerparticipatie en ongelijkheid in steden. Rotterdam: Kennis Werk Plaats Leefbare Wijken.

Eysink Smeets, M., H. Moors, M. Jans \& K. Schram (2013), De Bijzondere Belofte van Buurt Bestuurt. Maakt Buurt Bestuurt in de Rotterdamse praktijk de verwachtingen waar? En welke uitdagingen zijn er voor de toekomst?. Amsterdam: Lokaal Centraal.

Fijnaut, C., H. Moerland \& J. uit Beijerse (1991), Een boulevard in problemen: samenleving en criminaliteit in twee Rotterdamse buurten. Arnhem: Gouda Quint.

Fung, A. (2004), Empowered Participation. Reinventing Urban Democracy. Princeton/Oxford: Princeton University Press.

Gemert, F. van (2002), Marokkaanse Buurtvaders blokkeren integratie. Socialisme en Democratie, (59)7/8, 56-64.

Goldsmith, A. (2005), Police reform and the problem of trust. Theoretical Criminology, 9(4), 443-470.

Hobbes, T. ([1651] 1963), Leviathan. Cleveland: World Publishing Company.

Hoekman, H. (2011), Buurt Bestuurt: Een aanpak voor nu en in de toekomst. Wageningen/ Rotterdam.

Jackson, J., B. Bradford, E.A. Stanko \& K. Hohl (2012), Just Authority? Trust in the Police in England and Wales. Oxon: Routledge.

Jong, J.D.A. de \& W.J.M. de Haan (2000). Buurtvaders. Sociale controle, solidariteit en burgerlijke verantwoordelijkheid in de Marokkaanse gemeenschap. Tijdschrift voor Criminologie, (42)4, 383-393.

Land, M. van der, B. van Stokkom \& H. Boutellier (2014), Burgers in veiligheid. Een inventarisatie van burgerparticipatie op het domein van de sociale veiligheid. Den Haag: WODC.

Land, M. van der \& B. van Stokkom (2015), Burgerparticipatie en 'crafting' in het lokale veiligheidsbeleid. Tijdschrift voor Veiligheid, (14)1, 3-21.

Lindt, M. van der, G. Paradies, S. Emmert \& B. Boonstra (2012), Netwerken rond maatschappelijke initiatieven: Succes- en faalfactoren. Delft: TNO.

Lipset, S.M. \& W. Schneider (1983), The Confidence Gap. Business, Labor, and Government in the Public Mind. New York: The Free Press.

Locke, J. ([1690] 1988), Over het staatsbestuur. Meppel/Amsterdam: Boom. 
Lub, V. (2016), De burger op wacht. Het fenomeen 'buurtpreventie' onderzocht. Rotterdam: Kenniswerkplaats Leefbare Wijken.

Luhmann, N. (2000), Familiarity, confidence, trust: Problems and alternatives. In: D. Gambetta (red.), Trust: Making and Breaking Cooperative Relations. Electronic edition, Department of Sociology. University of Oxford, 94-107.

Marle, F. van (2015), Positieve veiligheid: een kwestie van vertrouwen. Tijdschrift voor Veiligheid, (14)1, 22-33.

Meurs, P. (2008), Sociaal vertrouwen: een kwestie van durf. Eerste Verweij-Jonker/SERlezing, Den Haag/Utrecht: SER/Verweij-Jonker Instituut, 10-23.

Ministerie van Binnenlandse Zaken en Koninkrijksrelaties (2013), Doe-democratie. Kabinetsnota ter stimulering van een vitale samenleving. Den Haag: www.rijksoverheid.nl.

Ombudsman Rotterdam (2007), Baas in eigen huis. 'Tja, wij komen eigenlijk voor alles'. Rapport van een ambtshalve onderzoek naar de praktijk van huisbezoeken. Rotterdam.

Ombudsman Rotterdam (2011), Kijken en bekeken worden. Een onderzoek naar de dagelijkse praktijk van de Rotterdamse interventieteams. Rotterdam.

Peeters, R. \& G. Drosterij (2011), Verantwoordelijke vrijheid. Responsabilisering van burgers op voorwaarden van de staat. Tijdschrift voor beleid, politiek en maatschappij, (38)2, 179-199.

Peeters, R. \& M. Schuilenburg (2014), De geest als aangrijpingspunt. De betekenis van gedragssturing in veiligheid, gezondheid en onderwijs. Justitiële verkenningen, 40(3), 9-23.

Putnam, R. (2000), Bowling Alone. The Collapse and Revival of American Community. New York: Simon \& Schuster.

Raad voor het openbaar bestuur (2012), Loslaten in Vertrouwen. Naar een nieuwe verhouding tussen overheid, markt én samenleving. Den Haag: Rob.

Raad voor Maatschappelijke Ontwikkeling (2013), Terugtreden is vooruitzien. Maatschappelijke veerkracht in het publieke domein. Den Haag: RMO.

Schnabel, P. (2010), Vertrouwen maakt het leven gemakkelijk en gevaarlijk. Management \& Organisatie, 6, 17-24.

Scholte, R.D. (2008), Burgerparticipatie in veiligheidsprojecten. In: H. Boutellier \& R. van Steden (red.), Veiligheid en burgerschap in een netwerksamenleving. Den Haag: Boom Juridische uitgevers, 223-242.

Schuilenburg, M. (2012), Orde in veiligheid. Een dynamisch perspectief. Den Haag: Boom Lemma.

Schuilenburg, M. (2015), Buurt Bestuurt: proeftuin van de participatiesamenleving. Tijdschrift voor Sociale Vraagstukken, 3, 42-45.

Schuilenburg, M. (2016), Naar een 'positieve veiligheid' in een hybride wereld. In: H. Oosterling \& R. Schepen (red.), Doordenken doorwerken. Intercultureel en ecosociaal denken en doen. Antwerpen/Apeldoorn: Garant, 129-141.

Schuilenburg, M. \& R. Peeters (2015), From Biopolitics to Mindpolitics: Nudging in Safety and Security Management. Open! Platform for Art, Culture \& the Public Domain, October 2nd, 1-7.

Schuilenburg, M. \& R. van Steden (2014), Positive Security. A Theoretical Framework. In: M. Schuilenburg, R. van Steden \& B. Oude Breuil (eds.), Positive Criminology. Reflections on Care, Belonging and Security. The Hague: Eleven International Publishing, 19-32.

Schuilenburg, M. \& R. van Steden (2015), Afgeschermd wonen in Nederland: een studie naar waarom mensen hiervoor kiezen en hoe zij omgaan met interne regelgeving. Tijdschrift voor Veiligheid, 14(3-4), 3-18. 
Schuyt, K. \& I. Verhoeven (2003), Institutioneel vertrouwen als bron van legitimiteit. Tijdschrift voor beleid, organisatie en politiek, 13(3), 11-14.

Shearing, C.D. (2006), Reflections on the refusal to acknowledge private governments. In: J. Wood \& B. Dupont (eds.), Democracy, Society and the Governance of Security. Cambridge: Cambridge University Press, 11-32.

Simon, J. (2007), Governing through Crime. How the War on Crime Transformed American Democracy and Created a Culture of Fear. Oxford: Oxford University Press.

Skogan, W.G. (2006), Police and Community in Chicago: A Tale of Three Cities. Oxford/New York: Oxford University Press.

Sociaal en Cultureel Planbureau (2012), Een beroep op de burger. Minder verzorgingsstaat, meer eigen verantwoordelijkheid?. Den Haag: Sociaal en Cultureel Planbureau.

Spierings, F. \& M. Meeuwisse (2012), Wijken van waarde. Digit 2012.

Stokkom, B. van (2008), Bange burgers, doortastende dienstverleners. Voorbij de retoriek van zelfredzaamheid. In: H. Boutellier \& R. van Steden (red.), Veiligheid en burgerschap in een netwerksamenleving. Den Haag: Boom Juridische uitgevers, 267-289.

Stokkom, B. van \& N. Toenders (2010), De sociale cohesie voorbij. Actieve burgers in achterstandswijken. Amsterdam: Pallas Publications.

Taylor, C. (1979), What's wrong with negative liberty?. In: A. Ryan (ed.), The Idea of Freedom. London: Oxford University Press, 175-193.

Terpstra, J. (2010), Het veiligheidscomplex. Ontwikkelingen, strategieën en verantwoordelijkheden in de veiligheidszorg. Den Haag: Boom Juridische uitgevers.

Terpstra, J. \& R. Kouwenhoven (2004), Samenwerken en netwerken in de lokale veiligheidszorg. Zeist: Uitgeverij Kerckebosch.

Tonkens, E. (2009), Burgerparticipatie en burgerinitiatief. In: E. Tonkens (red.), Tussen onderschatten en overvragen. Actief burgerschap en activerende organisaties in de wijk. Amsterdam: Sun Trancity, 135-141.

Tweede Kamer der Staten-Generaal (1985), Samenleving en criminaliteit. Een beleidsplan voor de komende jaren. Kamerstukken II 1984-1985, 18995, nr. 1-2.

Tyler, T. (2001), Public trust and confidence in legal authorities: What do majority and minority group members want from the law and legal institutions?. Behavioral Sciences and the Law, 19, 215-235.

Uitermark, J. (2014), Verlangen naar Wikitopia (oratie). Rotterdam: Erasmus Universiteit Rotterdam.

Veiligheidsindex Rotterdam (2014), www.rotterdam.nl/Clusters/BSD/Directie_Veiligheid/ Rotterdam_veilig/Wat_doet_de_gemeente/Raadsbrief_ondertekend_VI_2014.pdf.

Wacquant, L. (2008), Urban Outcasts. A Comparative Sociology of Advanced Marginality. Cambridge: Polity.

Wetenschappelijke Raad voor het Regeringsbeleid (2012), Vertrouwen in burgers. Amsterdam: Amsterdam University Press. 